Nevada

Environmental

Restoration

Project

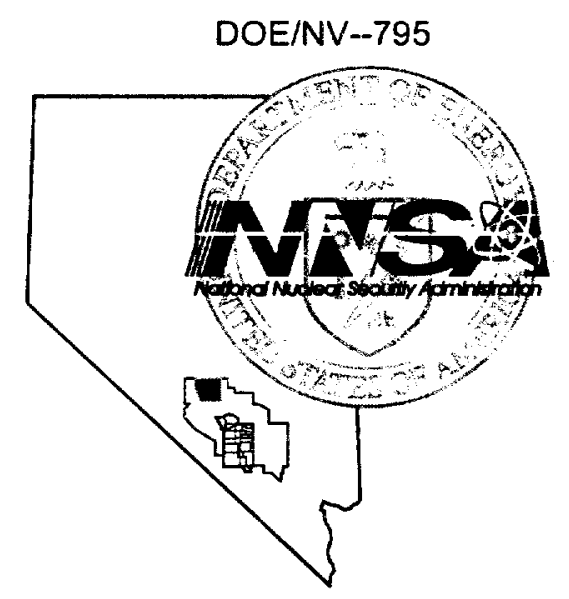

Post-Closure Inspection Report for Corrective Action Unit 453: Area 9 UXO Landfill Tonopah Test Range, Nevada Calendar Year 2001

Controlled Copy No.:

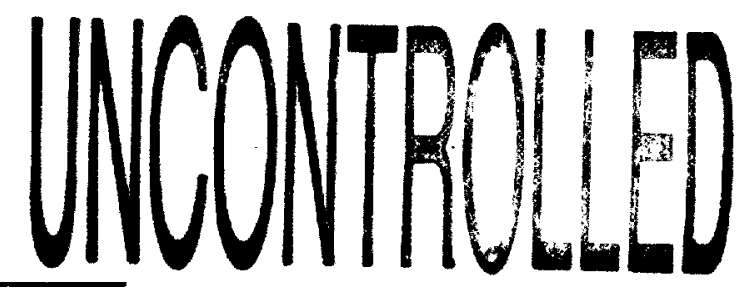

Revision: 0

January 2002

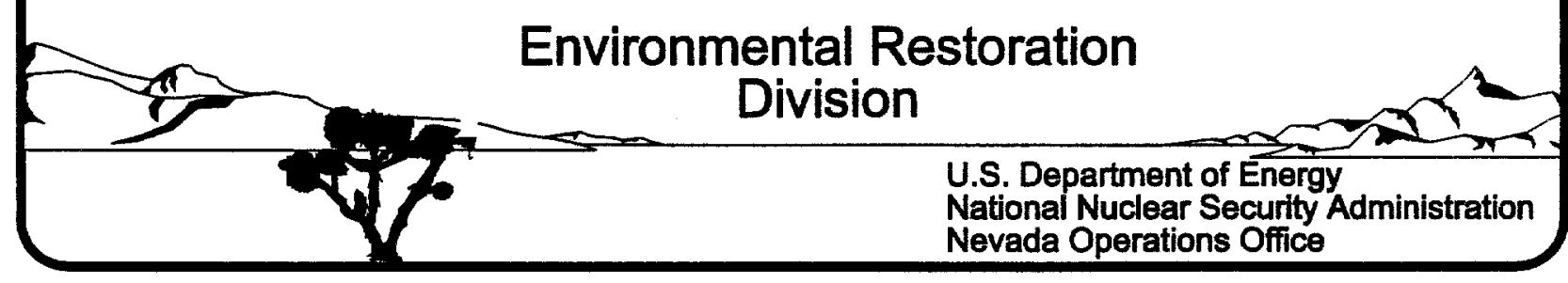




\section{DISCLAIMER STATEMENT}

Reference herein to any specific commercial product, process, or service by trade name, trademark, manufacturer, or otherwise, does not necessarily constitute or imply its endorsement, recommendation, or favoring by the U.S. Government or any agency thereof or its contractors or subcontractors.

\section{AVAILABILITY STATEMENT}

Available for sale to the public fromU.S. Department of Commerce National Technical Information Service 5285 Port Royal Road Springfield, VA 22161-0002

Telephone: 800.553 .6847

Fax: 703.605.6900

E-mail: orders@ntis.fedworld.gov

Online ordering: http://www.ntis.gov/ordering.htm

Available electronically at http://www.doe.gov/bridge

Available for a processing fee to U.S. Department of Energy and its contractors, in paper, fromU.S. Department of Energy

Office of Scientific and Technical Information

P.O. Box 62

Oak Ridge, TN 37831-0062

Telephone: 865.576 .8401

Fax: 865.576.5728

E-mail: reports@adonis.osti.gov 


\title{
POST-CLOSURE INSPECTION REPORT FOR CORRECTIVE ACTION UNIT 453: \\ AREA 9 UXO LANDFILL TONOPAH TEST RANGE, NEVADA CALENDAR YEAR 2001
}

\author{
Prepared for \\ U. S. Department of Energy \\ National Nuclear Security Administration \\ Nevada Operations Office \\ Work Performed Under Contract No. \\ DE-AC08-96NV11718
}

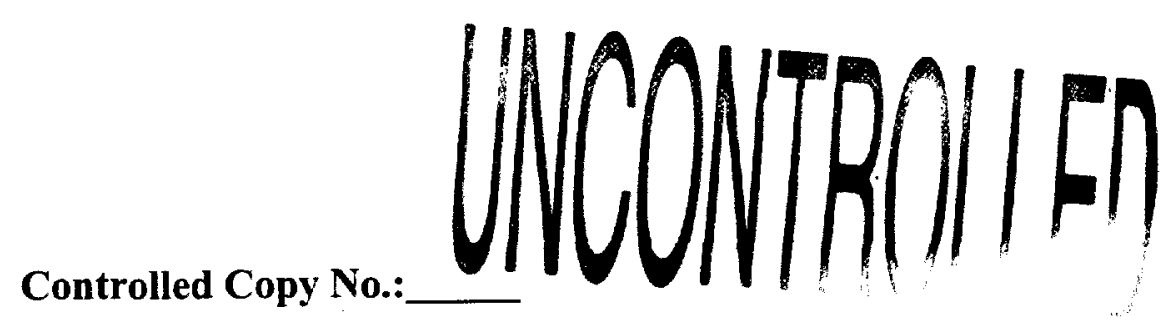

Revision: 0

January 2002 


\section{THIS PAGE INTENTIONALLY LEFT BLANK}

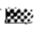

$\infty$

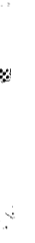

3

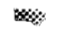

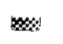

2 
DOE/NV-795

\section{POST-CLOSURE INSPECTION REPORT FOR CORRECTIVE ACTION UNIT 453: \\ AREA 9 UXO LANDFILL \\ TONOPAH TEST RANGE, NEVADA \\ CALENDAR YEAR 2001}

Approved by:

Janet L. Appenzeller-Wing, Project Manager

Industrial Sites Project

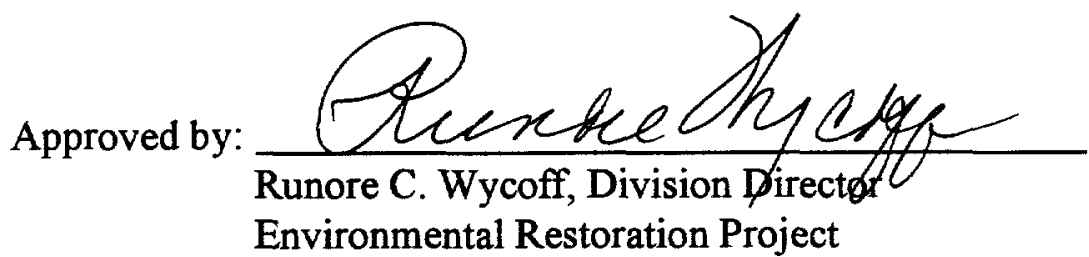

Date: $1 / 28 / 62$

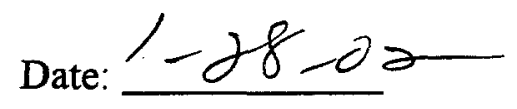




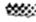

THIS PAGE INTENTIONALLY LEFT BLANK

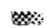

ex 


\section{TABLE OF CONTENTS}

$1.0 \quad$ INTRODUCTION $\ldots \ldots \ldots \ldots \ldots \ldots \ldots \ldots \ldots \ldots \ldots \ldots \ldots \ldots \ldots \ldots \ldots$

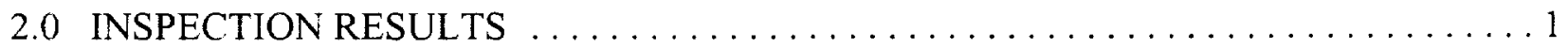

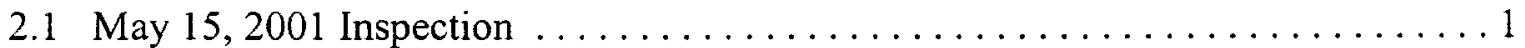

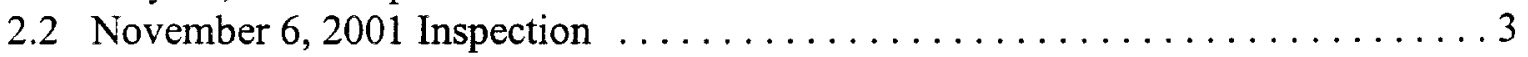

2.3 November 15, 2001 Maintenance and Repair Activities . . . . . . . . . . . 3

3.0 CONCLUSIONS AND RECOMMENDATIONS $\ldots \ldots \ldots \ldots \ldots \ldots \ldots \ldots \ldots$

\section{FIGURES}

FIGURE 1 - AREA 9 UXO LANDFILL CAU 453 LOCATION MAP . . . . . . . . . . 2

\section{ATTACHMENTS}

ATTACHMENT A - INSPECTION CHECKLISTS

ATTACHMENT B - FIELD NOTES

ATTACHMENT C - PHOTOGRAPH LOG AND PHOTOGRAPHS

DISTRIBUTION LIST 
Post-Closure Inspection Report

CAU No. 453

Revision: 0

Date:January 23, 2002
Area 9 UXO Landfill

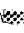

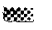

w)

的

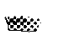

\section{THIS PAGE INTENTIONALLY LEFT BLANK}

\%

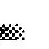

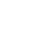

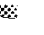

W.

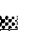

\%

$x$ 


\subsection{INTRODUCTION}

Post-closure monitoring requirements for the Area 9 Unexploded Ordnance Landfill (Corrective Action Unit [CAU] 453) (Figure 1) are described in Closure Report for Corrective Action Unit 453: Area 9 UXO Landfill, Tonopah Test Range, Nevada, report number DOE/NV--284, August 1999. The Closure Report (CR) was submitted to the Nevada Division of Environmental Protection (NDEP) on August 5, 1999. The CR (containing the Post-Closure Monitoring Plan) was approved by the NDEP on September 10, 1999.

As stated in Section 5.0 of the NDEP-approved CR, post-closure monitoring at CAU 453 consists of the following:

- Visual site inspections are conducted twice a year to evaluate the condition of the cover.

- Verification that the site is secure and the condition of the fence and posted warning signs.

- Notice of any subsidence, erosion, unauthorized excavation, etc., deficiencies that may compromise the integrity of the unit.

- Remedy of any deficiencies within 90 days of discovery.

- Preparation and submittal of an annual report.

Site inspections were conducted on May 15, 2001 and November 6, 2001. Both site inspections were conducted in accordance with the Post-Closure Monitoring Plan in the NDEP-approved $\mathrm{CR}$.

This report includes copies of the inspection checklists, photographs, recommendations, and conclusions. The Post-Closure Inspection Checklists are found in Attachment A, a copy of the field notes is found in Attachment B, and inspection photographs are found in Attachment C.

\subsection{INSPECTION RESULTS}

\subsection{May 15, 2001 Inspection}

The first inspection was completed on May 15, 2001. The perimeter fence and concrete monuments marking the landfill cells were in excellent condition. One sign had become detached from the fence, and a second sign had come loose at two corners. The remainder of the signs were securely attached to the fence and in excellent condition. Several small mammal burrows were observed inside the fence, but have not compromised the integrity of the waste cell covers. An area measuring approximately 3 by 6 meters ( 10 by 20 feet), located at the eastern end of trench number A9-1, appears to have subsided approximately 25.4 centimeters (10 inches). No cracks, erosion features, or settling were observed at the other landfill cell covers. Although closure activities did not include revegetation at the site, sparse plants were 
Revision: 0

Date: January 23, 2002
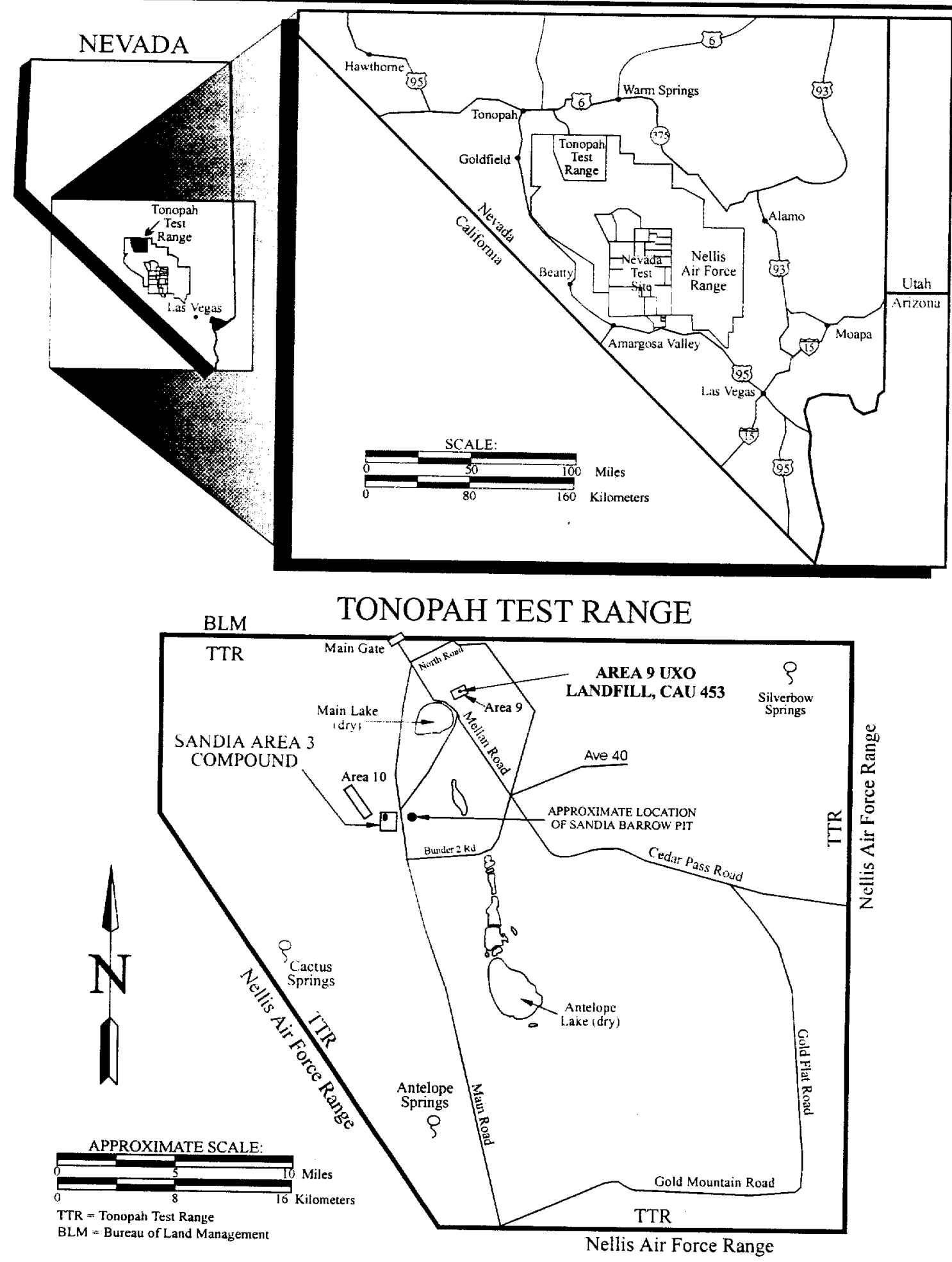

FIGURE 1

AREA9 UXO LANDFILL CAU 453

LOCATION MAP 
observed inside the fenced area, both on and off the landfill cover area. No maintenance or repairs to the site were made during this site inspection. Repair activities for the A9-1 cover subsidence area were scheduled for November 2001.

\subsection{November 6, 2001 Inspection}

The inspection was completed on November 6, 2001. The perimeter fence, concrete monuments, and site postings were in excellent condition. Two unattached warning sign were reattached to the fence using steel hog rings. Numerous small mammal burrows were observed inside the fence and were filled in by hand. The burrows have not compromised the integrity of the waste cell covers. The subsidence area in Landfill Cell A9-1 observed in the May 16, 2001 site inspection was still present. Repair work was scheduled for November 15, 2001. No cracks, erosion, or settling features were observed in the other landfill cover areas. Plant growth on the landfill cover was limited to sparse native grasses and halogeton. No further site maintenance or repairs were recommended.

\subsection{November 15, 2001 Maintenance and Repair Activities}

On November 15 and 16, 2001, the area of subsidence located at the east end of Landfill Cell A9-1 was repaired. Ninety-one cubic meters (120 cubic yards) of clean fill was placed in the area and compacted by back-dragging the area with the backhoe bucket. Final touch-up grading was made to bring the cover up to the pre-existing grade.

\subsection{CONCLUSIONS AND RECOMMENDATIONS}

The perimeter fence, monuments, and site postings are in excellent condition. Repair work to the eastern end of Landfill Cell A9-1 was completed and no other cracks, erosion features, or settling were observed in the other landfill cover area. Plant growth on the landfill cover is sparse and is limited to native grasses and shrubs.

No modifications or repairs to the cover, or changes in the frequency of site inspections, are recommended at this time. 
Posi-Closure Inspection Report

CAL No. 453

Area 9 UXO Landfill

Revision: 0

Date:January 23, 2002

THIS PAGE INTENTIONALLY LEFT BLANK

:

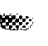

$\infty$

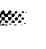

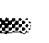

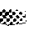

$\infty$

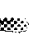


Date:Ianuary 23, 2002

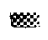

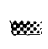




\section{CAU 453: AREA 9 UXO LANDFILL, POST-CLOSURE INSPECTION CHECKLIST}

\begin{tabular}{|c|c|}
\hline Date of Last Inspection: $\mathbb{W}$ Nortm ber 2000 & Reason for Last Inspection: $B_{1} \in$ nneref \\
\hline Responsible Agency: NNSA/NV $S N E R$ & 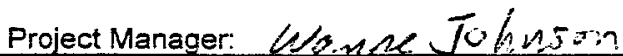 \\
\hline \multicolumn{2}{|l|}{ Inspection Date: $15 \mathrm{May} \mathrm{Cl}$} \\
\hline Inspector (name, title, organization): Bred $J_{t<i}$ & Task Mapezan BN \\
\hline
\end{tabular}

A. GENERAL INSTRUCTIONS

1. All checklist items must be completed and detailed comments made to document the results of the site inspection. The completed checklist is part of the field record of the inspection. Additional pages should be used as necessary to ensure that a complete record is made. Attach the additional pages and number all pages upon completion of the inspection.

3. Any checklist line item marked by an inspector in a SHADED BOX, must be fully explained or an appropriate reference to previous reports provided. The purpose of this requirement is to provide a written explanation of inspector observations and the inspector's rationale for conclusions and recommendations. Explanations are to be placed on additional attachments and cross-referenced appropriately. Explanations, in addition to narrative, will take the form of sketches, measurements, annotated site maps.

4. The site inspection is a walking inspection of the entire site including the perimeter and sufficient transects to be able to inspect the entire surface and all features specifically described in this checklist.

5. A standard set of color $35 \mathrm{~mm}$ photographs (or equivalent) is required. In addition, all anomalous features or new features (such as changes in adjacent area land use) are to be photographed. A photo log entry will be made for each photograph taken.

6. This unit will be inspected biannually with formal reporting to the Nevada Division of Environmental Protection to be done annually. The annual report will include an executive summary, this inspection checklist with field notes and photo log attached, and recommendations and conclusions.

\section{B. PREPARATION (To be completed prior to site visit) \\ 1. Site as-built plans and site base map reviewed. \\ 2. Previous inspection reports reviewed. \\ a. Were anomalies or trends detected on previous inspections? \\ b. Was maintenance performed?}

3. Site maintenance and repair records reviewed.

a. Has site repair resulted in a change from as-built conditions?

b. Are revised as-builts available that reflect repair changes?

C. SITE INSPECTION (To be completed during inspection)

\begin{tabular}{|c|c|l|}
\hline YES & NO & EXPLANATION \\
\hline$\sqrt{ }$ & & \\
\hline$V$ & & \\
\hline & $\sqrt{ }$ & \\
\hline & $\sqrt{ }$ & \\
\hline & & \\
\hline & $\sqrt{ }$ & NA \\
\hline & $\sqrt{ }$ & NA \\
\hline YES & NO & EXPLANATION \\
\hline
\end{tabular}

1. Adjacent off-site features within watershed areas.

a. Have there been any changes in use of adjacent area?

b. Are there any new roads or trails?

c. Has there been a change in the position of nearby washes?

d. Has there been lateral excursion or erosion/deposition of nearby washes?

e. Are there new drainage channels?

f. Change in surrounding vegetation?

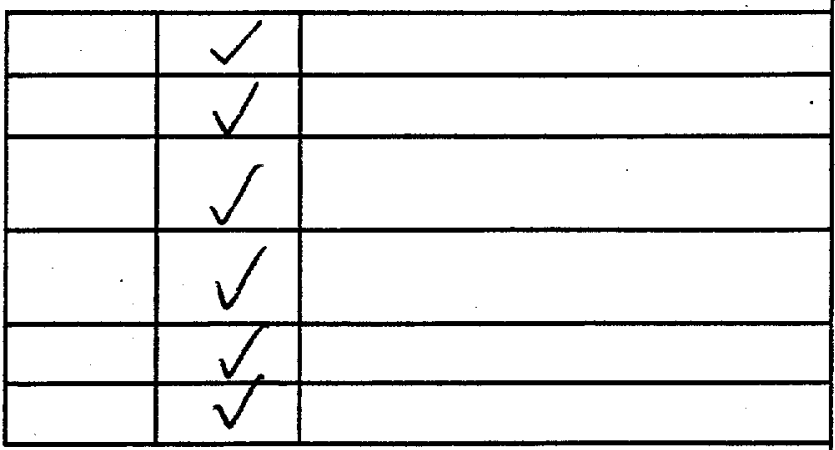

2. Security fence, signs.

a. Displacement of fences, site markers, boundary markers, or monuments?

b. Have any signs been damaged or removed? (Number of signs replaced: $\$$

c. Were gates locked?

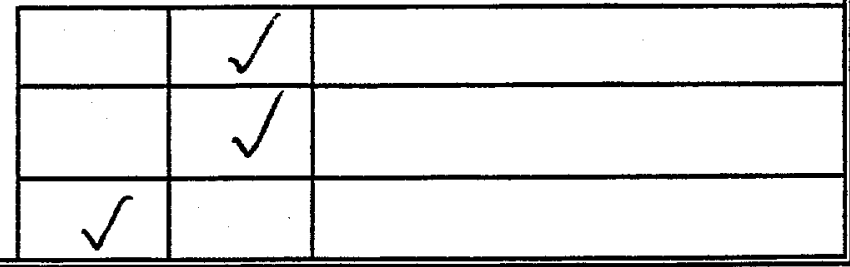




\section{CAU 453: AREA 9 UXO LANDFILL, POST-CLOSURE INSPECTION CHECKLIST}

3. Waste Unit cover.

a. Is there evidence of settling?

b. Is there cracking?

c. Is there evidence of erosion around the cap (wind or water)?

d. Is there evidence of animal burrowing?

e. Have the site markers been disturbed by man or natural processes?

f. Is vegetation present?

g. Do natural processes threaten to integrity of any cover or site marker?

h. Other?

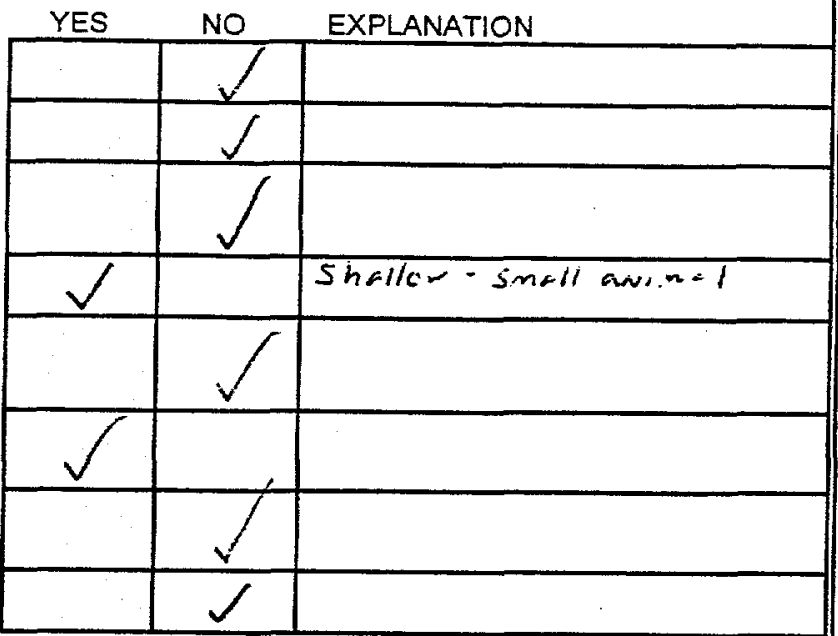

4. Photo Documentation

a. Has a photo log been prepared?

c. Number of photos exposed

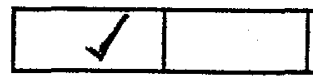

\section{FIELD CONCLUSIONS}

1. Is there an imminent hazard to the integrity of the unit? (Immediate report required)

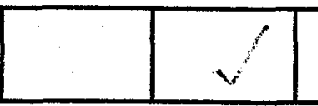

Person/Agency to whom report made:

2. Are more frequent inspections required?

3. Are existing maintenance/repair actions satisfactory?

4. Is other maintenance/repair necessary?

5. Is current status/condition of vegetative cover satisfactory?

6. Rationale for field conclusions:

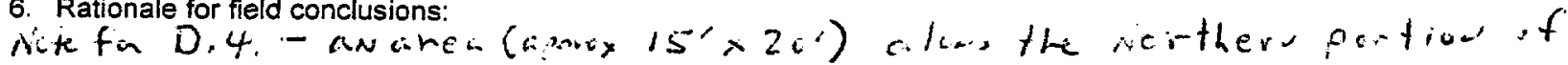
tremeh A9-1 cinesces to be Netierbly lader thas the suiresdies

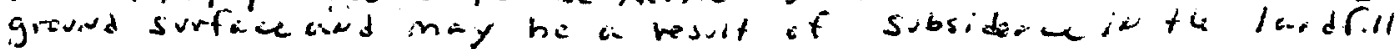

\section{E. CERTIFICATION}

I have conducted an inspection of the Area 9 UXO Landfill, CAU 453, at the TTR in accordance with the Post-Closure Inspection Plan (see Closure Report) as recorded on this checklist, attached sheets, field notes, photo logs, and photographs.

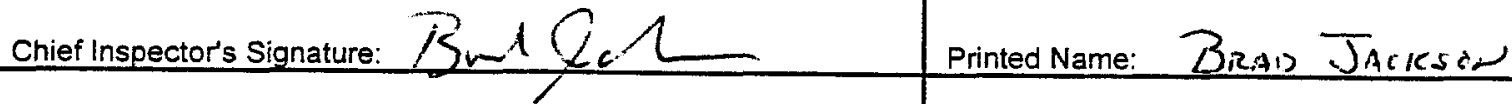

Title: TASK MANACER Date: $\quad 15, M$ ay $O 1$ 
CAU 453: AREA 9 UXO LANDFILL, POST-CLOSURE INSPECTION CHECKLIST

\begin{tabular}{|l|l|}
\hline \hline Date of Last inspection: $15 \mathrm{May} 2001$ & Reason for Last inspection: Bi annuel \\
\hline Responsible Agency: BNER NNSA/NV & Project Manager: Wayne Johnson BNER \\
\hline Inspection Date: 6 November 2001 & \\
\hline Inspector (name, title, organization): Kevin B. Camplell Technecal Lead BN ER \\
\hline Assistant inspector (name, title, organization): NA
\end{tabular}

A. GENERAL INSTRUCTIONS

1. All checklist items must be completed and detailed comments made to document the results of the site inspection. The completed checklist is part of the field record of the inspection. Additional pages should be used as necessary to ensure that a complete record is made. Attach the additional pages and number all pages upon completion of the inspection.

2. Any checklist line item marked by an inspector in a SHADED BOX, must be fully explained or an appropriate reference to previous reports provided. The purpose of this requirement is to provide a written explanation of inspector observations and the inspector's rationale for conclusions and recommendations. Explanations are to be placed on additional attachments and cross-referenced appropriately. Explanations, in addition to narrative, will take the form of sketches, measurements, annotated site maps.

3. The site inspection is a walking inspection of the entire site including the perimeter and sufficient transects to be able to inspect the entire surface and all features specifically described in this checklist.

4. A standard set of color $35 \mathrm{~mm}$ photographs (or equivalent) is required. In addition, all anomalous features or new features (such as changes in adjacent area land use) are to be photographed. A photo log entry will be made for each photograph taken.

5. This unit will be inspected biannually with formal reporting to the Nevada Division of Environmental Protection to be done annually. The annual report will include an executive summary, this inspection checklist with field notes and photo log attached, and recommendations and conclusions.

\begin{tabular}{|c|c|c|c|}
\hline B. PREPARATION (TO be completed prior to site visit) & YES & No & EXPLANATION \\
\hline \multicolumn{4}{|l|}{ 1. Site as-built plans and site base map reviewed. } \\
\hline \multirow{3}{*}{$\begin{array}{l}\text { 2. Previous inspection reports reviewed. } \\
\text { a. Were anomalies or trends detected on previous } \\
\text { inspections? }\end{array}$} & $\nu$ & & . \\
\hline & & & $\begin{array}{l}\text { small asea }(20<15) \text { of strided } \\
\text { near trench } A 9-1 \text { noted on last }\end{array}$ \\
\hline & & $\swarrow$ & scheduled th $11 / 14 / 01$ \\
\hline \multirow{3}{*}{$\begin{array}{l}\text { 3. Site maintenance and repair records reviewed. } \\
\text { a. Has site repair resulted in a change from as-built } \\
\text { conditions? } \\
\text { b. Are revised as-builts available that reflect repair changes? }\end{array}$} & & & \\
\hline & & & $M / A$ \\
\hline & & & will be following $11 / 14 / 01$ rep \\
\hline C. SITE INSPECTION (TO be completed during inspection) & YES & No & EXPLANATION \\
\hline
\end{tabular}

1. Adjacent off-site features within watershed areas.

a. Have there been any changes in use of adjacent area?

b. Are there any new roads or tralis?

c. Has there been a change in the position of nearby washes?

d. Has there been lateral excursion or erosion/deposition of nearby washes?

e. Are there new drainage channels?

f. Change in surrounding vegetation?

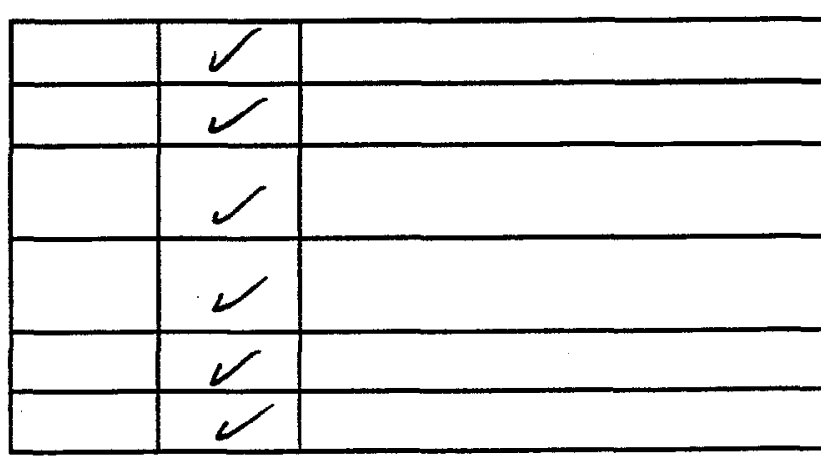

2. Security fence, signs.

a. Displacement of fences, site markers, boundary markers, or monuments?

b. Have any signs been damaged or removed? (Number of signs replaced:

8

c. Were gates locked?

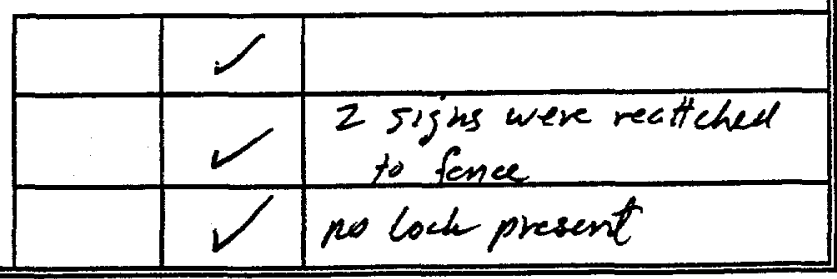




\section{CAU 453: AREA 9 UXO LANDFILL, POST-CLOSURE INSPECTION CHECKLIST}

3. Waste Unit cover.

a. Is there evidence of settling?

b. Is there cracking?

c. Is there evidence of erosion around the cap (wind or water)?

o. Is there evidence of animal burrowing?

e. Have the site markers been disturbed by man or natural processes?

f. Is vegetation present?

9. Do natural processes threaten to integrity of any cover or site marker?

h. Other?

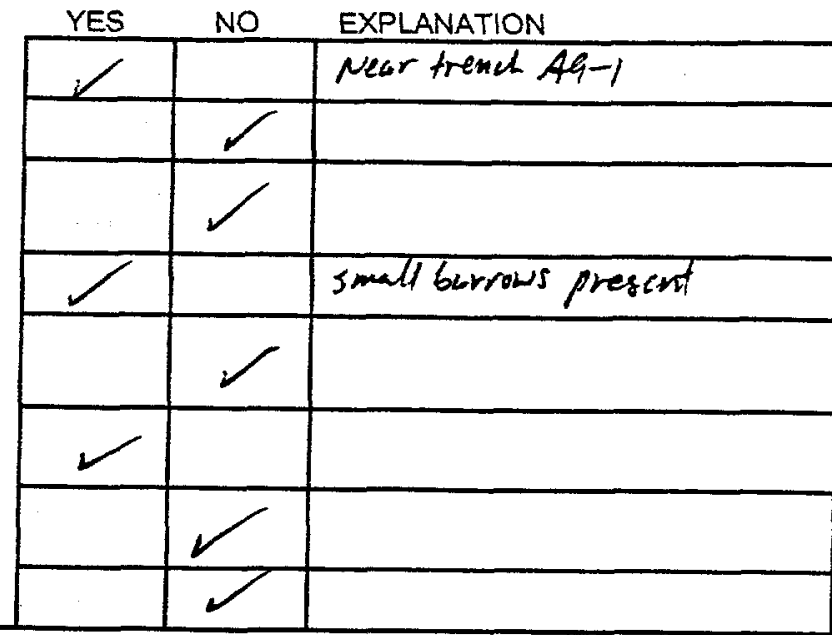

4. Photo Documentation

a. Has a photo log been prepared?

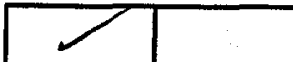

c. Number of photos exposed

\section{FIELD CONCLUSIONS}

1. Is there an imminent hazard to the integrity of the unit? (Immediate report required)

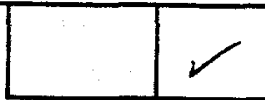

Person/Agency to whom report made:

2. Are more frequent inspections required?

3. Are existing maintenance/repair actions satisfactory?

4. Is other maintenance/repair necessary?

5. Is current status/condition of vegetative cover satisfactory?

6. Rationale for field conclusions:

Based on observations minor repairwork to the eatern end of $/ 4$ alfill cll AG-1 is newed. All other aceas, all fencing, sigis, ard monumemt are in excellent cendition:

\section{E. CERTIFICATION}

I have conducted an inspection of the Area 9 UXO Landfill, CAU 453, at the TTR in accordance with the Post-Closure Inspection Plan (see Closure Report) as recorded on this checklist, attached sheets, field notes, photo logs, and photographs.

Chief Inspector's Signature: Tum B. Qumplell $\quad$ Printed Name: Kevin B. Oamplell

Title: BNER Technich Lead Date: 6 Nonember ZOOI 
Post-Closure Inspection Report

CAUNo. 453

Area 9 UXO Landfill

Revision: 0

Date:January 23, 2002

ATTACHMENT B

\section{FIELD NOTES}


Revision: 0

Date:January 23, 2002

(1)

$\nLeftarrow$

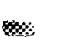

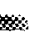

THIS PAGE INTENTIONALLY LEFT BLANK

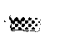

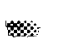

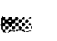

s.

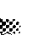


IITLE

PROJECT NO.

15

Work continued from Page pl/A TTR Port Closure Irspic. BOOK NO. 15 May 01

630 - recerve clemance fram ASI to accss Aner 9.

645 - arive at CAU Area 9 uxO baudfill

- walk the perimite of fere ard visually inspet tie 5 . Le. The ferre was in goed conditien but ore sige was

5 On the groved and ore sise was int conned to the fere at two coverers. There were numerars burrows withid the ferued avea. Ill corcerete morrmerts were in good shope ard visble.

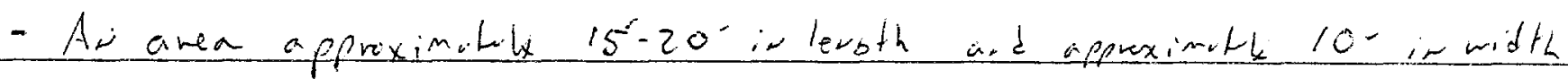
0 iv the Nortleast ejd of trerch A9-1 has appareatle subsided. This area was roticably lower thas the surface grode of the remoirder of the site.

$5=1400$ - five-Powts Lavd fill

16 Mayol

- walk the pevirete of fencirs ard visurlly inspet th sile. The ferwed aven is well coreved by vegutution aud show to sisurs of evosion. Numerars burrows ane preset alors the fercelice ard withir the fercing. Sore surface dobns is presect aloug the south east marsic of the site within the fercies.

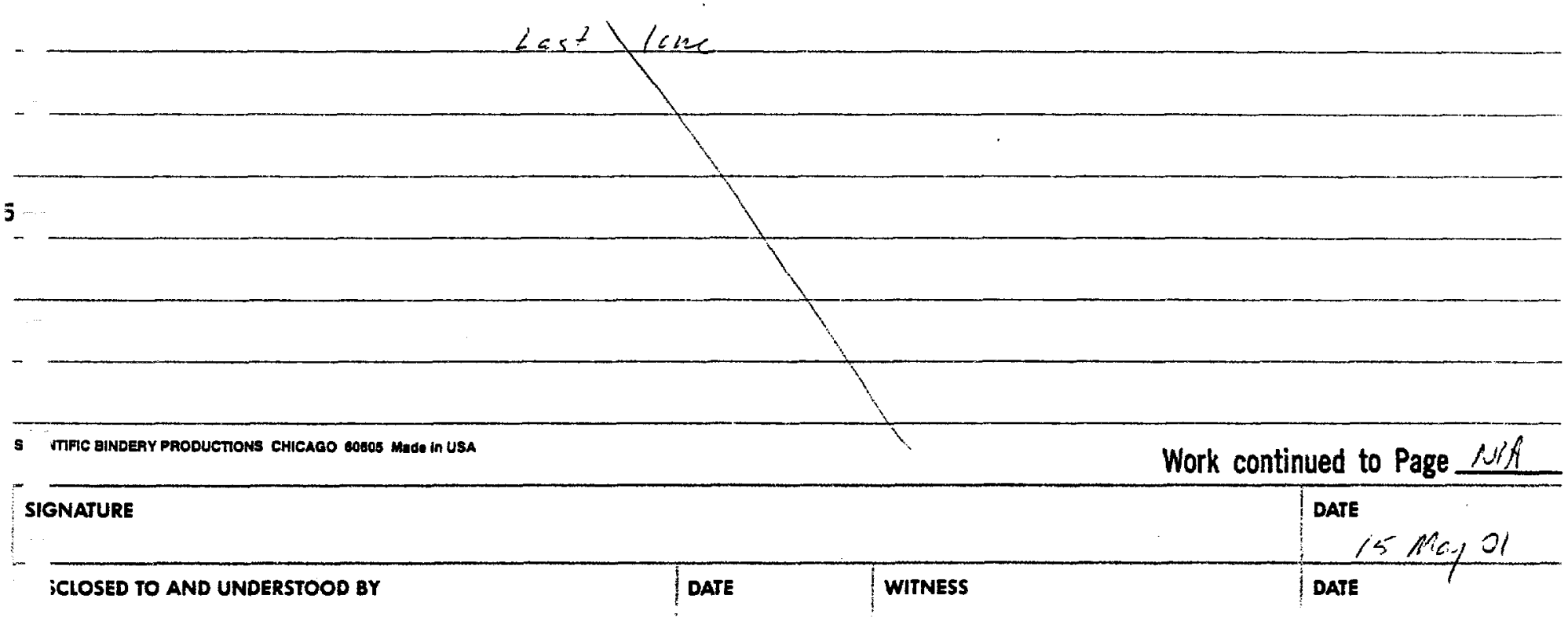




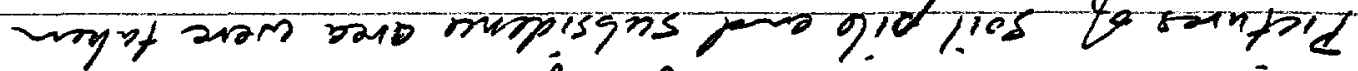

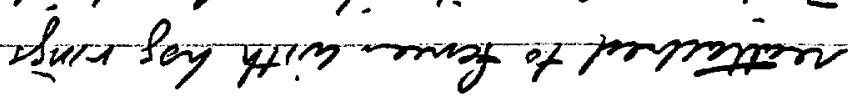

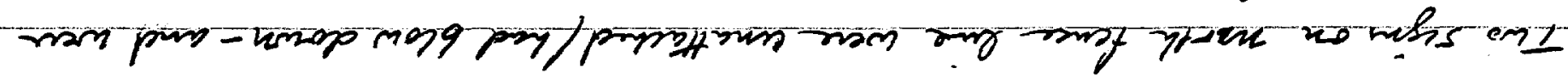

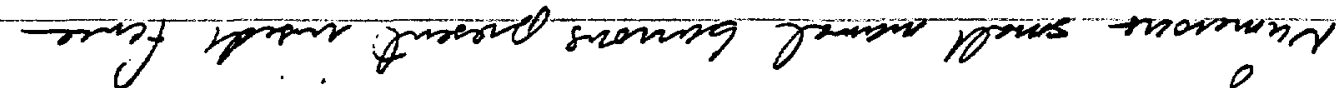

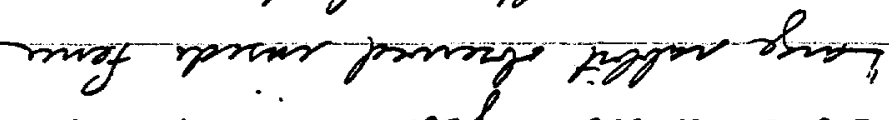

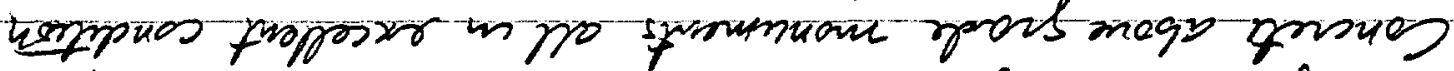

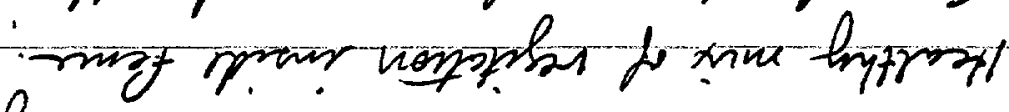

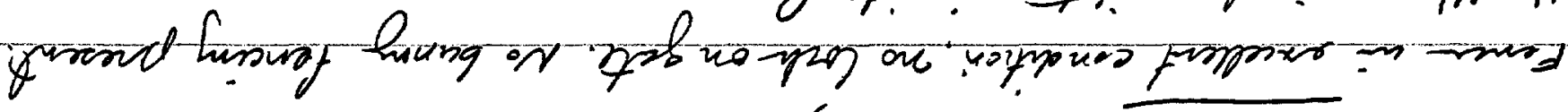

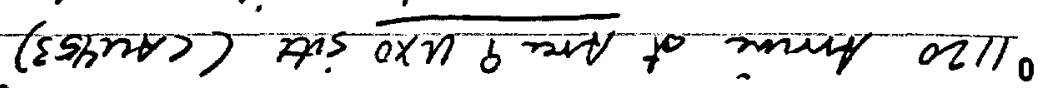

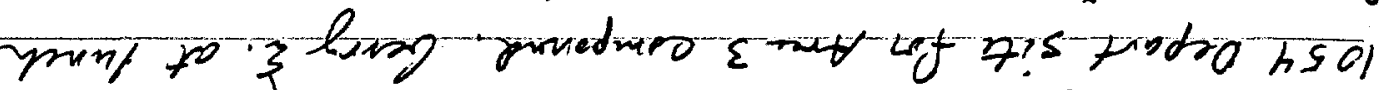

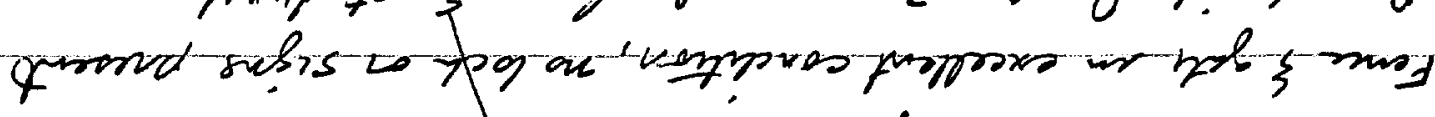

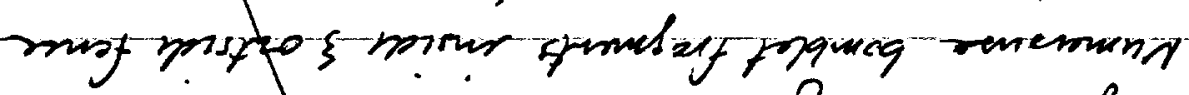

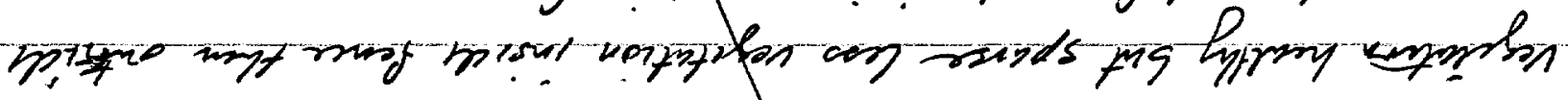

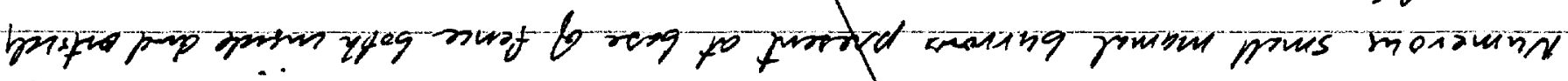

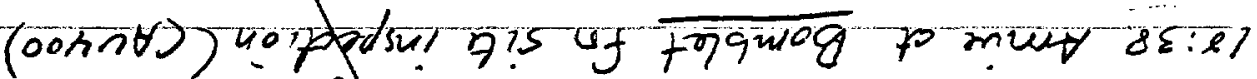

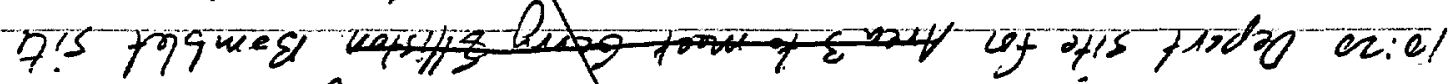

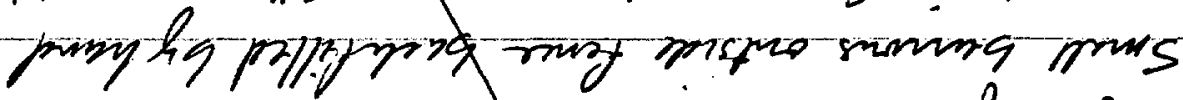

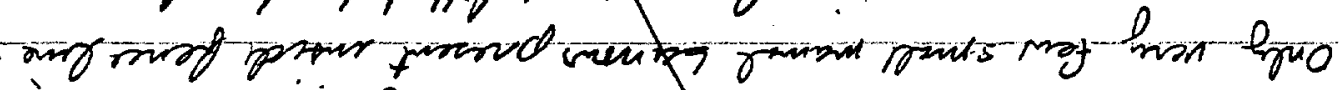

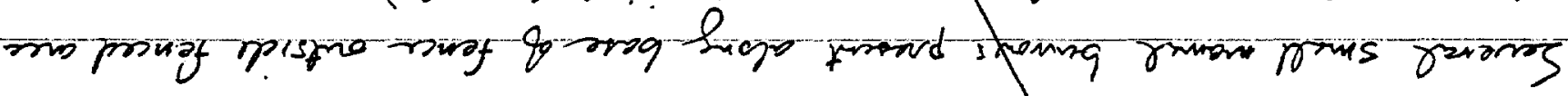

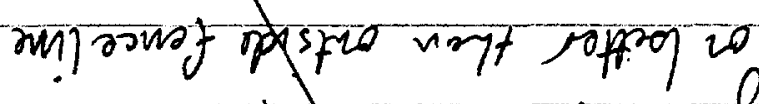

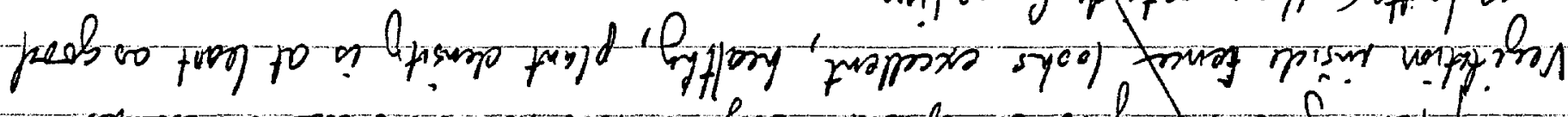

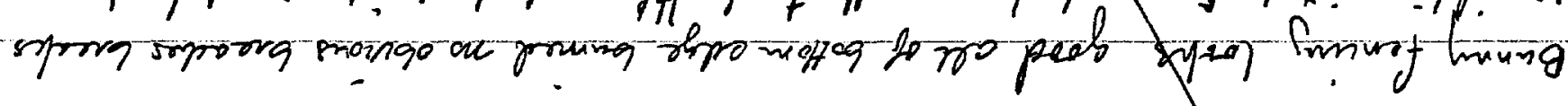
u.? s

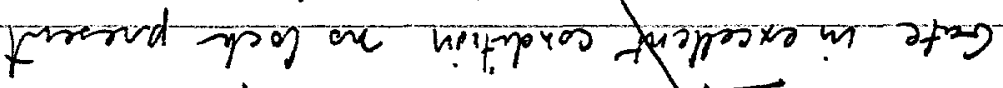

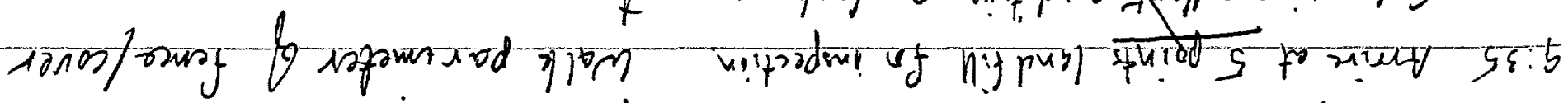

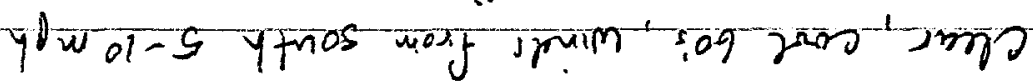

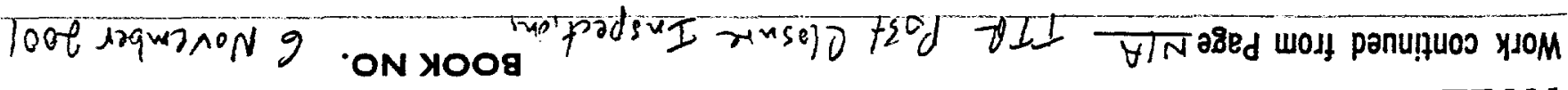


Post-Closure Inspection Report

CAU No. 453

Area 9 UXO Landfill

Revision: 0

Date:January 23, 2002

\section{ATTACHMENT C}

\section{PHOTOGRAPH LOG AND PHOTOGRAPHS}


Post-Closure Inspection Report

CAU No. 453

Area 9 UXO Landîll

Revision: 0

Date:January 23, 2002

\section{THIS PAGE INTENTIONALLY LEFT BLANK}

\%

.

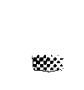

亦:

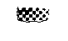


PHOTOGRAPH LOG

\begin{tabular}{|c|c|l||}
\hline $\begin{array}{c}\text { PHOTO } \\
\text { NUMBER }\end{array}$ & DATE & \multicolumn{1}{c|}{ DESCRIPTION } \\
\hline \hline 1 & $05 / 15 / 2001$ & $\begin{array}{l}\text { View to northwest from outside of perimeter fence near gate. } \\
\text { Concrete monuments indicate locations of the northeast and } \\
\text { southwest ends of Landfill Cells A9-1, A9-2, and A9-3. Signs } \\
\text { on south fence line visible and in good condition }\end{array}$ \\
\hline 2 & $05 / 15 / 2001$ & $\begin{array}{l}\text { View to west from outside the southeast corner of perimeter } \\
\text { fence. Concrete monuments indicate locations of the landfill } \\
\text { cells. }\end{array}$ \\
\hline 3 & $05 / 15 / 2001$ & $\begin{array}{l}\text { View to west from inside of the perimeter fence showing the } \\
\text { A9-1 Landfill Cell cover subsidence area in the foreground. } \\
\text { Concrete monuments indicate locations of the landfill cells. }\end{array}$ \\
\hline 4 & $05 / 15 / 2001$ & $\begin{array}{l}\text { View to east from inside of perimeter fence. Concrete } \\
\text { monuments indicate locations of the corners of the Landfill Cells } \\
\text { A9-1, A9-2, and A9-3. Sparse vegetation inside fence is healthy } \\
\text { native grass and brush species. }\end{array}$ \\
\hline 5 & $11 / 06 / 2001$ & $\begin{array}{l}\text { View to the north from outside perimeter fence. Gate signs and } \\
\text { landfill cell corner monuments are visible and in excellent } \\
\text { condition. }\end{array}$ \\
\hline 6 & $11 / 06 / 2001$ & View to west from outside perimeter fence. \\
\hline 7 & $11 / 06 / 2001$ & $\begin{array}{l}\text { View to east of subsidence area at eastern end of A9-1 Landfill } \\
\text { Cell. Sparse vegetation of native grasses, shrubs, and halogeton } \\
\text { are present inside the fenced area. }\end{array}$ \\
\hline 8 & $11 / 06 / 2001$ & $\begin{array}{l}\text { View to northeast from outside perimeter fence at southwest } \\
\text { corner. }\end{array}$ \\
\hline
\end{tabular}


Post-Closure Inspection Report

CAU No. 453

Area 9 UXO Landfill

Revision: 0

Date:January 23, 2002

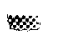

戠:

\&

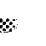

$\times$

\section{THIS PAGE INTENTIONALLY LEFT BLANK}

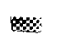

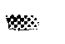

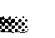

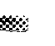

;

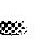

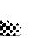

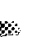

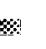




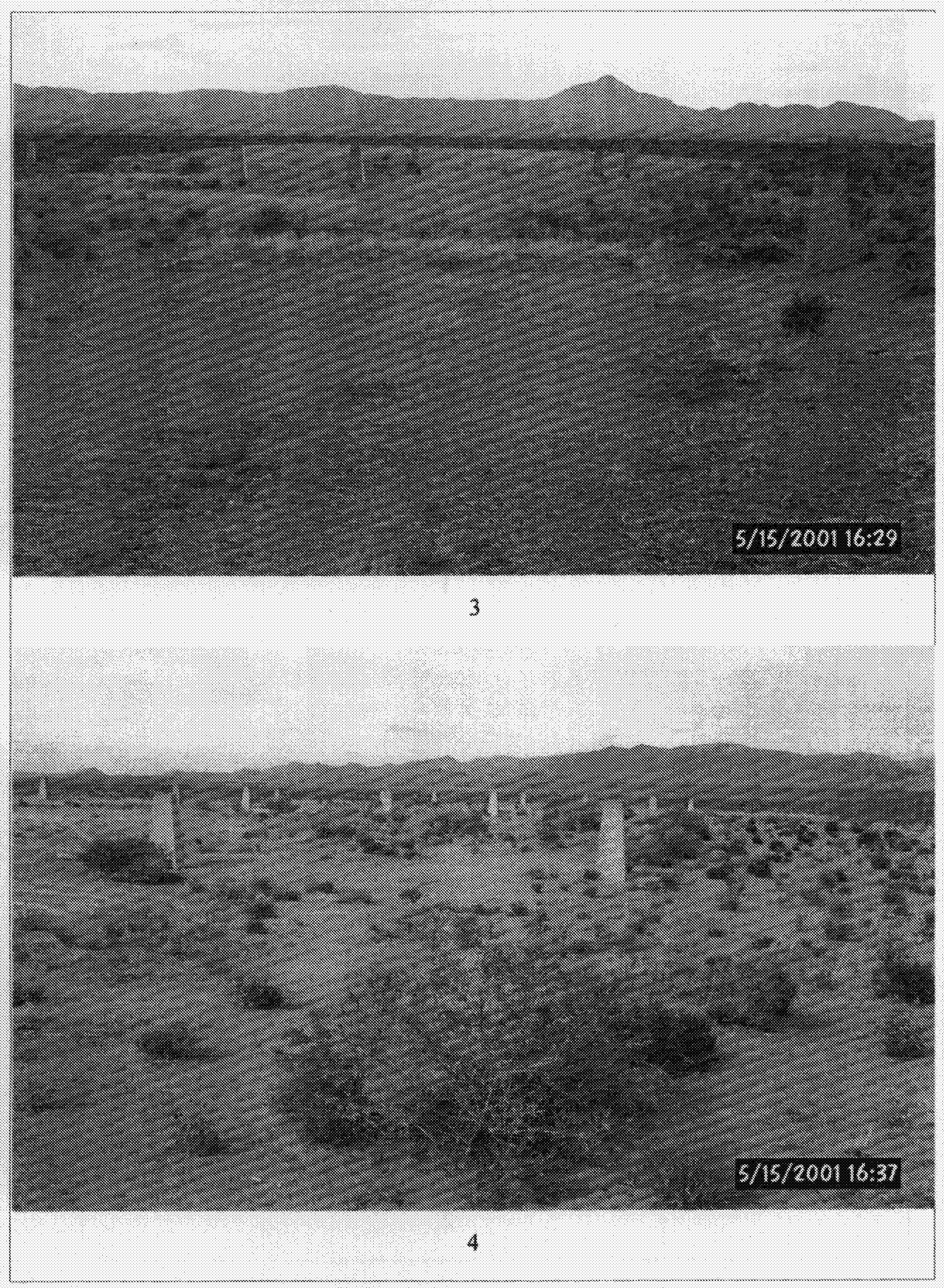







Post-Closure Inspection Report

CAU No. 453

Area 9 UXO Landfill

Revision: 0

Date:January 23, 2002

\section{DISTRIBUTION LIST}





\section{DISTRIBUTION LIST}

*Provide copy of initial distribution of Revision 0; remainder of list gets Revision 0 if approved without changes. The entire list receives Revision 1, if issued.

\section{Nevada Department of Environmental Protection}

Paul Liebendorfer

2 (Controlled)*

Bureau of Federal Facilities

Division of Environmental Protection

333 W. Nye Lane, Room 138

Carson City, NV 89706-0866

Supervisor, Las Vegas Office

1 (Controlled)*

Bureau of Federal Facilities

Division of Environmental Protection

555 E. Washington, Suite 4300

Las Vegas, NV 89010-1043

\section{U.S. Department of Energy}

Janet Appenzeller-Wing

1 (Uncontrolled)*

Project Manager

Environmental Restoration Division

U.S. Department of Energy

National Nuclear Security Administration

Nevada Operations Office

P.O. Box $98518 \mathrm{M} / \mathrm{S} 505$

Las Vegas, NV 89193-8518

Kevin Cabble

1 (Uncontrolled)*

Environmental Restoration Division

U.S. Department of Energy

National Nuclear Security Administration

Nevada Operations Office

P.O. Box $98518 \mathrm{M} / \mathrm{S} 505$

Las Vegas, NV 89193-8518

Sabrina Lawrence

1 (Controlled)*

Environmental Restoration Division

U.S. Department of Energy

National Nuclear Security Administration

Nevada Operations Office

P.O. Box $98518 \mathrm{M} / \mathrm{S} 505$

Las Vegas, NV 89193-8518 


\section{DISTRIBUTION LIST (Continued)}

\section{U.S. Department of Energy (continued)}

U.S. Department of Energy

1 (electronic copy)

Office of Scientific and Technical Information

P.O. Box 62

Oak Ridge, TN 37831-0062

U.S. Department of Energy

National Nuclear Security Administration

1 (Controlled) \&

Nevada Operations Office

1 (Uncontrolled)

Public Reading Facility

P.O. Box $98521 \mathrm{M} / \mathrm{S}$ NLV040

Las Vegas, NV 89193-8521

U.S. Department of Energy

National Nuclear Security Administration

1 (Uncontrolled)

Nevada Operations Office

Technical Information Resource Center

P.O. Box $98521 \mathrm{M} / \mathrm{S} 505$

Las Vegas, NV 89193-8521

\section{Bechtel Nevada}

Correspondence Control

Bechtel Nevada

P.O. Box $98521 \mathrm{M} / \mathrm{S}$ NLV008

Las Vegas, NV 89193-8521

Environmental Management Library

Bechtel Nevada

1 (Uncontrolled)*

P.O. Box 98521 N/S NLV080

Las Vegas, NV 89193-8521

Kevin Campbell

1 (Uncontrolled)*

Bechtel Nevada

1 (Uncontrolled)*

P.O. Box $98521 \mathrm{M} / \mathrm{S}$ NTS306

Las Vegas, NV 89193-8521

Ann Heidema

1 (Uncontrolled)

Bechtel Nevada

P.O. Box $98521 \mathrm{M} / \mathrm{S}$ NLV022

Las Vegas, NV 89193-8521 


\section{DISTRIBUTION LIST (Continued)}

\section{Bechtel Nevada (continued)}

Ronald Jackson

1 (Uncontrolled)*

Bechtel Nevada

P.O. Box $98521 \mathrm{M} / \mathrm{S}$ NTS306

Las Vegas, NV 89193-8521

Wayne Johnson

1 (Uncontrolled)*

Bechtel Nevada

P.O. Box $98521 \mathrm{M} / \mathrm{S}$ NTS306

Las Vegas, NV 89193-8521

Steve Nacht

1 (Uncontrolled)*

Bechtel Nevada

P.O. Box $98521 \mathrm{M} / \mathrm{S}$ NTS306

Las Vegas, NV 89193-8521

\section{$\underline{\text { IT Corporation }}$}

Lynn Kidman

1 (Uncontrolled)*

IT Corporation

P.O. Box $93838 \mathrm{M} / \mathrm{S} 439$

Las Vegas, NV 89193-8521

Garry Romano

1 (Controlled)

IT FFACO Support Office

IT Corporation

P.O. Box $93838 \mathrm{M} / \mathrm{S} 439$

Las Vegas, NV 89193-8521

\section{State of Nevada}

Manager, Northern Nevada

FFACO Public Reading Facility.

1 (Controlled) \&

Nevada State Library and Archives Federal Publications

1 (Uncontrolled) 100 North Stewart Street

Carson City, NV 89701-4285 